\title{
Australian otolaryngology research
}

After seven years of editing the Australian Supplement, this will be my last editorial. I believe the association with the JLO has been a great success, and this has now allowed us to produce two consecutive supplements with 100 per cent Australian content.

There is no doubt that Australian academic otolaryngology is in a good place, due in no small part to the Garnett Passe and Rodney Williams Memorial Foundation. It is encouraging to hear the Foundation has new ideas to ensure that past progress is built upon and academic growth continues well into the future. In addition to the established chairs and fulltime clinical academic positions, many surgeons with visiting medical officer or part-time staff contracts also have active research programmes, often involving basic science as well as clinical aspects. This all bodes well for the future of this publication.

In this edition of the Supplement, we have three review articles. Two assess variously the controversial topic of sub-total tonsil surgery ${ }^{1}$ and the rare but devastating condition of bilateral sudden onset sensorineural hearing loss. ${ }^{2}$ The third is perhaps the most extensive review to date of the epidemiology of chronic otitis media in Australian Indigenous children. ${ }^{3}$

Rhinology research dominates the original research section, with papers looking at irrigation bottle contamination, ${ }^{4}$ patients' perception of which side of the nose is blocked, ${ }^{5}$ and the positive and negative aspects of home-made nasal irrigation solutions. ${ }^{6}$ Frey's syndrome can be a troublesome complication following parotid surgery, and a paper outlining the clinical and aesthetic outcomes of free fat grafting completes this section. ${ }^{7}$

Two case reports on novel techniques for managing rare conditions complete the supplement. ${ }^{8,9}$
I wish my successor every success and would like to thank the Editorial Board for their hard work and support over the years, in addition to the reviewers, who ensure that published papers remain of a high quality. Finally, the staff and editorial team at the JLO and the ASOHNS council and staff have provided the enthusiasm and resources to make it all happen. I will be forever in their debt.

A S CARNEY

Editor

Australian Supplement of the JLO

References

1 Wood JM, Cho M, Carney AS. Role of subtotal tonsillectomy ('tonsillotomy') in children with sleep disordered breathing. J Laryngol Otol 2014;128(suppl 1):S3-S7

2 Sara SA, Teh BM, Friedland P. Bilateral sudden sensorineural hearing loss: review. J Laryngol Otol 2014;128(suppl 1):S8-S15

3 Jervis-Bardy Jake, Sanchez L, Carney AS. Otitis media in Indigenous Australian children: review of epidemiology and risk factors. J Laryngol Otol 2014;128(suppl 1):S16-S27

4 Tan NC-W, Drilling AJ, Jardeleza C, Wormald P-J. Is nasal steroid spray bottle contamination a potential issue in chronic rhinosinusitis? J Laryngol Otol 2014;128(suppl 1):S28-S33

5 Chin D, Malek J, Pratt E, Marcells G, Sacks R, Harvey RJ. Patient self-assessment in discriminating the more obstructed side in nasal breathing. J Laryngol Otol 2014;128(suppl 1):S34-S39

6 Lilic N, Waldvogel-Thurlow S, Douglas RG. Physical characteristics of commercial and home-made nasal lavage solutions. J Laryngol Otol 2014;128(suppl 1):S40-S43

7 Chan LS, Barakate MS, Havas TE. Free fat grafting in superficial parotid surgery to prevent Frey's syndrome and improve aesthetic outcome. J Laryngol Otol 2014;128(suppl 1):S44-S49

8 Shilton H, Hodgson M, Burgess G. Hyperbaric oxygen therapy for sudden sensorineural hearing loss in large vestibular aqueduct syndrome. J Laryngol Otol 2014;128(suppl 1):S50-S54

9 Sim G, Vijayasekaran S. Novel use of Coblation technology in an unusual congenital tracheal stenosis. J Laryngol Otol 2014; 128(suppl 1):S55-S58 